tained some better tokens of consciousness than the greater or less resemblance of the movements in question to such movements as our conscious selves are in the habit of executing.

M. FOSTER

\section{Meyer's Exploration of New Guinea}

FEW persons can have read Dr. Meyer's account of his recent adventurous and very successful journey with 'more interest than myself; but I confess I was surprised to find that the translator of my book should have misunderstood what $I$ had stated, and so create a difference between us where none exists. He says (speaking of Dorey) that I " have not given a correct impression of the natives of the surrounding hills and mountains, separating them in some way from the inhabitants of the coast, as smaller, uglier, not mop-headed," \&c. ; and that he finds on the other hand, that "there is no generic difference at all between the Papooas of the mountain and the Papooas of the coast, except such differences as we find everywhere between the highlanders and coast inhabitants of the same race." Now I say exactly the same thing: "From these (sketches) and the captain's description, it appeared that the people of Arfak vere similar to those of Dorey." ("Malay Archipelago," 3rd Ed. p. 505.) Dr. Meyer however, probably refers to what I say of the people of one hill village, close to Dorey: "The inhabitants seemed rather uglier than those at Dorey village. They are, no doubt, the true indigenes of this part of New Guinea, living in the interior, and subsisting by cultivation and hunting. The Dorey-men, on the other hand, are shore dwellers, fishers, and traders in a small way, and have thus the character of a colony who have migrated from another district. These hillmen, or Arfaks, differed much in physical features. They were generally black, but some were brown like Malays. Their hair, though always more or less frizzly, was sometimes short and matted," \&c. (p. 499). I can only suppose that the word "differed" in the above passage was taken to mean "differed from the Dorey people," whereas the context shows that it means "differcd among themselves," or varied, which would have been a better word. In the preceding page I have stated of the inhabitants of Dorey: "The majority have short woolly hair ;" so that there is no difference from them in that respect. In all [ have written about the Papuans I have maintained that the people of New Guinea and of all the immediately surrounding islands are of one race, with very unimportant local differences; and I do not think my remark, that the people of one village were "rather uglier" than those of another, three miles off, justifies the idea that I supposed there was any "difference," in an ethnological sense, between them. I cannot find that I have said a word about difference of stature.

The great success of both Messrs. D'Albertis and Meyer in penetrating inland in New Guinea will, it is to be hoped, induce other travellers to attempt the exploration of the far larger and less known southern portion. Two Europeans, with a small steam launch and a Malay crew, would, no doubt, be able to penetrate a long way up some of the larger rivers, and establish a station from which exploration of the central mountains might be effected. There is now no portion of the globe so completely unknown as this, or which promises such great results for every branch of Natural History.

ALFREJ R. WALLACE

\section{Deep-sea Sounding and Deep-sea Thermometers}

WITH reference to the discussion which has recently been carried on in NATURE as to the deep-sea thermometers, I hope that perhaps the following statement may tend to put the matter at rest.

One of Negretti's thermometers was exbibited at the Royal United Service Institution at a lecture, March II, I 859 , by Admiral FitzRoy, who then spoke of them "as thermometers peculiarly constructed, self-registering," \&c. The construction of these thermometers had been fuliy described in the "First number of Meteorological Papers, 1857," and was subsequently given in a "Treatise on Meteorological Instruments," published by Negretti and Zambra in I864. The peculiarity of these thermometers was mentioned in the Hydrographic Instructions to Captain Dayman of the Cyclops Sounding Expedition, dated May 29, I857. These facts are sufficient to show the ample publication of the device in question for protecting the bulbs against pressure.

I know from Dr. Miller himself that he did not know of Negretti's plan. In his paper in the Royal Society Proceedings, he calls the one which he describes a "simple expedient." I am not aware of any just claim on the part of Mr. Casella to the principle of the invention.

I consider that the practice of instrument makers designating by their names instruments which they have not invented, is most reprehensible.

London, Dec. 9

ROBER'T If. SCOT?

We have received a letter on this subject also from $\mathrm{Mr}$. Casella, but as there is nothing in it bearing on the real point at issue, we do not print it. The above letter from Mr. Scott renders it clear to us, and it will doubtless be also clear to our readers, that the whole credit of the double bulb belongs to Messrs. Negretti and Zambra. We quite agree also with $\mathrm{Mr}$. Scott's closing remarks. This correspondence must now cease. -ED.]

The Dutch Photographs of the Eclipse of $187 \mathrm{r}$

Aвоuт a year ago Dr. Schellen kindly sent me two paper copies of the Java photograph, one of them was stated to be of the size of the original negative and the other was an enlargement of about ten and a half diameters, with a delicately soft outline and much detail in the corona. On comparing this with the Indian photographs I found that though the outline of the corona corresponded depression for depression with the two Indian series, yet there was great difference in the detail of the lower parts. The question therefore arose, Was such difference to be regarded as proof of enormous change in the corona in the course of about an hour, during the passage of the totality shadow from India to Java?

I had carefully compared and catalogued the details visible upon the original negatives of the two Indian series, and had found no structure in the one that could not be traced in the other, but the details of the new Java photograph were quite of a different character, lumpy, and in more definite masses. On mentioning this to Lord Lindsay he informed me that he had other copies of the Java negatives which he had received directly from Prof. Oudemans and which were almost structureless. Mr. Davis undertook a critical comparison of the two Java photographs, and pointed out that in spite of the striking dissimilarity of the paper prints, they were evidently both taken from the same original, for they each showed a faint scratch and three minute photographic flaws in the same rem lative positions. It was impossible to assert that the one was a good print and the other a very bad one, for in the photograph with the delicate corona the moon's limb was soft and hazy, while with the poor corora the limb was perfectly sharp and definite. We had only one course left, and that was to infer that the softening and details had been produced artificially. Having detected manipulation in the corona, we naturally suspected it in the moon's limb, and thus arose my remark at the meeting of the Astronomical Society, that the sharp edges of the irradiation under the prominences might have been artificially produced by stopping out the moon, or rather by stopping out the hazy irradiation which presents so marked a feature, especially under the prominences in the Indian photographs, as well as in those taken in 1870

There is still a little mystery which requires clearing up about the hazy irradiation. No trace of it is to be found in the copies of the Shelbyville photograph taken by Mr. Whipple in 1869 , nor (as we now learn) in the Java photographs, although the action of the light has been greater in these than in some of the Indian and 1870 negatives, which show it as a very marked feature. We know that under ordinary circumstances hazy irradiation is produced by reflection at the hinder surface of thie glass on which the photograph is taken, and that its amount may be greatly reduced by backing the plate, during its exposure, with wet paper, so as to produce a film of water instead of film of air immediately behind the plate, thus causing nearly all the light to be transmitted instead of reflected at its back surface. Yet the Baikul photographs (and I understand also the Cadiz photograph of 1870 ) were backed with wet paper, and still show the irradiation very markedly.

The cause of the ellipticity of the dark moon touched upon by Prof. Oudemans seems to me to involve some very interesting questions. It is remarkable that the ellipticity does not occur in all eclipse photograpbs. After making allowance for the moon's motion during 40 seconds in the enlargement from the Cadiz negative, I may say that I have not been able to detect any difference between the polar and equatorial diameters in any of the 1870 photographs. 